\title{
Gender Sensitive Psychiatry and Feminist Therapy
}

\section{Cinsiyete Duyarlı Psikiyatri: Feminist Terapi}

\author{
Veysel Kaplan
}

\begin{abstract}
:
Gender, which expresses the roles given by a society to men and women unlike the biological sex of women and men, leads to discrimination and inequalities in many fields such as education, health, economy and social status. Today, the women who live in patriarchal societies are restricted by the pressure of gender roles, economic dependence, heavy responsibilities, negative attitudes, stereotypes towards women. All these cause women to often experience psychological problems like depression, anxiety, fear and low self-respect. The biomedical model and mainstream therapy approaches applied as a treatment for mental problems of the women are especially inadequate for producing permanent solutions for the problems experienced by women due to considering the symptoms only as biological changes, supporting traditional gender roles and ignoring characteristics such as culture, sex and ethnicity. As an alternative method, feminist therapy gives both the therapist and the client the opportunity of social and emotional development in daily life. Feminist therapy aims at helping the individuals discover their strengths rather than a disease-oriented approach and enabling individuals to get rid of their feelings of guilt and to acquire new skills. Feminist therapy is a modern approach specifically fulfilling the needs of women and aims at radical changes in society.
\end{abstract}

Keywords: Psychiatric Approaches, Gender Sensitivity, Feminist Therapy

PhD, RN, Faculty of Health Sciences, Nursing Department, Harran University, Şanliurfa-Turkey,Orcid İd: https://orcid.org/ 0000-0001-9082-1379

Address of Correspondence/Yazışma Adresi: Faculty of Health Sciences, Nursing Department, Harran University, ŞanlıurfaTurkey, E-mail: vyslkpln@ hotmail.com

Date of Received/Geliș Tarihi: 17.02.2021, Date of Revision/Düzeltme Tarihi: 28.04.2021, Date of Acceptance/Kabul Tarihi: 05.05.2021, Date of Online Publication/Çevirimiçi Yayın Tarihi: 01.09.2021

Citing/Referans Gösterimi: Kaplan, V. (2021). Gender Sensitive Psychiatry and Feminist Therapy., Cyprus Turkish Journal of Psychiatry \& Psychology, 3(3): 211-16

(C) 2021 The Author(s). Published by Cyprus Mental Health Institute / Cyprus Turkish Journal of Psychiatry and Psychology (www.ktppdergisi.com). This article is an open access article distributed under the terms and conditions of the Creative Commons Attribution 4.0 license which permits use, sharing, adaptation, distribution and reproduction in any medium or format, provided the original work is properly cited and is not used for commercial purposes. http://creativecommons.org/licenses/by/4.0/ 


\section{Öz:}

Toplumsal cinsiyet, kültürün kadın ve erkeğe biyolojik cinsiyetlerinden farklı olarak verdiği toplumsal rolleri ifade etmekte ve toplumda eğitim, sağlık, ekonomi ve sosyal statü gibi bir çok alanda ayrımcılığa ve eşitsizliklere yol açmaktadır. Bugün ataerkil toplumlarda yaşayan kadınlar, toplumsal cinsiyet rollerinin baskısı, ekonomik bağımlılıkları, yüklendikleri ağır sorumluluklar, maruz kaldıkları olumsuz tutumlar ve kalıp yargılarla sınırlandırılmaktadırlar. Tüm bunlar, kadınların sıklıkla depresyon, anksiyete, korku ve düşük benlik saygısı gibi psikolojik problemler yaşamasına neden olmaktadır. Kadınların ruhsal sorunlarının tedavisi olarak uygulanan biyomedikal model ve ana akım terapi yaklaşımları da, semptomları sadece biyolojik değişimler olarak görmesi, geleneksel toplumsal cinsiyet rollerini desteklemesi ve kültür/cinsiyet/etnik köken gibi özellikleri göz ardı etmesi gibi durumlar nedeniyle özellikle kadınların yaşadığı sorunlara kalıcı çözümler üretmede yetersiz kalmaktadır. Alterantif bir yöntem olarak feminist terapi ise, hem terapiste hem de danışana günlük hayatta sosyal ve duygusal gelişim firsatı vermektedir. Feminist terapi, hastalık odaklı bir yaklaşımdan ziyade bireylerin güçlü yönlerini keşfetmelerine yardımcı olmayı, bireylerin suçluluk duygularından kurtulmalarını ve yeni beceriler edinmelerini sağlamayı amaçlamaktadır. Feminist terapi, özellikle kadınların ihtiyaçlarını karşılayan ve toplumda radikal değişimleri hedefleyen modern bir yaklaşımdır.

Anahtar Kelimeler: Psikiyatrik Yaklaşımlar, Cinsiyete Duyarlıklık, Feminist Terapi

\section{Introduction}

Almost all the physical and mental illnesses encountered in today's societies arise from the combination of biological, psychological and social factors. However, mental illnesses are specifically significant in terms of affecting the individual, family and society in all age groups in a negative way (Knapp, 2007). According to the report of the World Health Organization, $12.3 \%$ of the worldwide disease burden is comprised of mental illnesses. Today, $25 \%$ of the world's population suffer from mental illnesses in a part of their lives and 4 of the 10 diseases which cause the highest disease burden are mental illnesses. Moreover, the incidence of the disease may differ depending on the factors such as gender, age and socio-cultural level (WHO, 2009).

When the mental illnesses that are likely to be seen in all the individuals in the society are examined in terms of genders, serious differences are observed between women and men. In the studies, the prevalence of the risk of major depression was found by $24 \%$ and $12 \%$, the risk of common anxiety disorder by $6.6 \%$ and $3.6 \%$, the misuse of alcohol by $2.6 \%$ and $12.7 \%$ and the somatoform disorders by $13.3 \%$ and $3.5 \%$ for female and male genders, respectively (Eaton et al., 2012; Keskin, Ünlüoğlu, Bilge and Yenilmez, 2013; Yüksel, 2014). These statistical differences between genders are believed to result from the effects of the gender-specific roles and approaches existing in the society and culture (Sayar, 2003).

Social problems such as domestic violence, sexual abuse, negligence, substance abuse and economic problems in undeveloped and developing patriarchal societies and social responsibilities determined for the genders in a culture affect women much more negatively (Yardim, 2001). Generally, male individuals express their feelings with substance abuse or aggressive behaviors while facing problems, however, this may not be reflected as a problem in the reports. On the other hand, the social pressure faced by women when they express their problems leads to symptoms such as depression or anxiety. This causes women to be diagnosed more often with mental illnesses.
As a result, the socially determined gender roles give rise to such huge differences between genders in terms of mental illnesses (Sayar, 2003).

\section{Reflection of Gender Roles on Women}

The sexual identity of an individual, in other words, being a woman or a man, is a crucial point which determines the meaning and the responsibilities given to the individual in the society. However, there are large differences between the statuses of women and men in the society even though there are only a few biological differences between them (Topuz and Erkanl1, 2016). Conceptually, the biological differences between women and men, which exist as two basic elements of the society, are called sex (Dündar, 2012). Gender, which determines the social existence of the individual, refers to what has been determined socially and culturally with a meaning different from the biological sex (Altınova and Duyan, 2013; Çakır, 2016). Gender, which points at the characteristics of being a woman or a man acquired within the socialization process and culture, defines the socially determined roles, responsibilities and behaviors of women and men in a culture (Altınova and Duyan, 2013). This concept has led to the emergence of the roles based on genders embracing the cultural values of being a man and a woman over time. However, this role sharing has resulted in the designation of lower statuses for women and apparent inequalities in fields such as health, social life, culture, politics and economy due to the social perspective on women (Altınova and Duyan, 2013; Ersoy, 2009; Üner, 2008).

While being strong, resilient, confident, brave and extrovert and seeking the rights are set as male roles, being polite, beautiful, shy, self-sacrificing and loving her home are usually determined as female roles as of childhood in the society. Women are generally evaluated with negative characteristics by the society and their social existence is only accepted with their motherhood roles due to those roles attributed to women (Dökmen, 2010; Sezgin, 2015). Being exposed to various restrictions in the working life, women can also not take part in decision-making 
mechanisms. The society only approves low-status jobs (cleaning worker, service personnel) or specific fields (teaching, nursing) for women. In many societies, women, who still cannot make use of educational opportunities as much as men, do not receive sufficient services in the field of health. For this reason, they experience physiological health problems such as sexually transmitted diseases and unwanted pregnancies. All these negative circumstances cause women to experience psychological traumas, hence affecting their mental health negatively (Bal, 2014; Dökmen, 2010; Sezgin, 2015).

\section{Reflection of Gender Roles on Women's Mental Health}

A mentally healthy individual can evaluate himself/herself realistically, has self-confidence, has gained his/her independence, has not lost some of his/her commitments, knows when to be upset or to be happy and lives in harmony with his/her environment (Öz and Bahadır Y1lmaz, 2009). When all these traits are considered, social environments such as family, school, work and immediate circle can affect the psychological status of the individuals with their interventions (Craske and Stein, 2016; Kessler, 2007; Wittchen, 2011). Therefore, genders roles, as a social factor in addition to the mixture of genetic and biological factors, are of vital importance for the mental health and illnesses of the individuals (Türmen, 2003).

Gender roles determine the behaviors, responsibilities and role to be exhibited by the individuals in the society. Thus, with gender roles, it is determined how a woman will turn out (passive, emotional, easy-going, dependent and selfsacrificing) or how a man will turn out (logical, strict, tough and protective).

When assessed in this context, most psychological disorders become compatible with female roles (Çakır, 2016; Powell and Greenhause, 2010). Femininity, which is considered compatible with a more coward role than masculinity, becomes more prone to having phobias or anxiety disorders, causing emotionalism and depression, inability to bear pain and somatization disorders (psychological pain) (Sayar, 2003; WHO, 2002).

Ideal femininity determined by today's societies is a profile which includes multiple roles and running the working life, household chores and motherhood together. However, women who have to run multiple roles together may have several psychological problems (Sayar, 2003; Türmen, 2003). Moreover, early marriages and adolescent pregnancies, poverty, violence, abusing, raping, honor killings and many other factors traumatize women and affect their mental health in a negative way (Türmen, 2003). Additionally, it is inevitable that a woman who feels obliged to be slim and beautiful because of the ideal body image/beauty perception, which is presented via the media and arises in relation to the gender roles, frequently experience anxiety and eating disorders together with selfdissatisfaction (Çepikkurt and Coşkun 2010; Özcan, 2013).

An important finding regarding gender and mental health is related to marital status. Studies show that married women and divorced/single men experience more mental problems and they are diagnosed with more illnesses. For the opposite situation, married men and single/divorced women feel better mentally (Türmen, 2003). Regarding the gender roles, the institution of marriage, where female roles are felt more dominantly, is seen to be a positive factor for men while it impairs the mental health of women.

As a result, gender roles, which lead to the problems experienced by women, and the resulting discrimination affect women's psychology negatively. It is visible that the traditional female role is not good for women's mental health, on the contrary, it can cause depression, anxiety, pain and several difficulties (Koyun, Taşkın and Terzioğlu, 2011; Pehlivan, 2015). It is thought that the gender roles laid on women have a significant effect on the differentiation between genders within the mental illness statistics.

\section{Criticism against Classic Psychiatric Approaches}

Mental illnesses, which lead to the loss of abilities, social and economic losses due to occurring cognitive damages on individuals, are complex disorders necessitating continuous physical and social care in addition to causing loss of familial or social roles (Aston and Coffeya, 2012; Moller and McLoughlin, 2013). For this reason, diagnosis, treatment and rehabilitation of mental diseases have a distinct significance. However, when the statistics are reviewed, it is seen that women cannot receive $76-85 \%$ of the help they need to cope with their mental problems especially in many developing countries (WHO, 2013). Women who can have the chance of getting help face the sexist attitudes and interventions of the mental health personel (Herman, 2016; Pehlivan, 2015). The reason is the effect of gender stereotypes in the diagnosis of the mental illnesses. The gender-based perspective causes certain dichotomies between diagnosis and treatment, and thus, the evaluation of the genders with different criteria. Due to this perspective, women are diagnosed with depression more quickly than men even in symptoms identical to each other. This is related to the consideration of women as oversensitive and delicate by the culture (Türmen, 2003; WHO, 2000).

In classic psychiatric approaches, mental health professionals, first of all, try to find a diagnostic response to the problems stated by the client. This model, which is used by the professionals to explain the illnesses, directly affects the evaluation process, explanations related to the cause of the diagnosis and the treatment process (Evans et al., 2005; Pehlivan, 2015).

The biomedical model correlates the illness with biological changes and only drugs are used for the treatment. The biomedical model is prone to pathologizing the mental problems of women and associates the source of the problems only to the difference in the biological nature of women (Davison and Neale, 2004; Pehlivan, 2015).

From mainstream approaches, the psychoanalytic approach attributes the problems of women to the Electra complex in general. According to this theory, girls in early childhood have sexual fantasies related to the male authority figure living in the house (father, brother, grandfather etc.); they feel admiration for that person or experience penis envy. Problems such as harassment, depression or low self-respect experienced by women are explained with this theory (Herman, 2016; Pehlivan, 2015). 
According to the Cognitive-Behavioral approach, the emerging problems of the individuals result from inaccurate cognitive thinking or incorrect learning processes.

For example, when automatic negative thoughts such as 'Earth is a dangerous place' and 'I cannot trust the opposite sex' occur in individuals, they are believed to be changed with methods like systematic desensitization (facing the feared object step by step).

Here, the situations causing the individuals to fear are considered normal, and an attempt is made to make them get used to the situations which lead to their illness and are avoided (Pehlivan, 2015; Stapleton, Taylor and Asmundson, 2007).

Even though the implementation of the biomedical model or mainstream therapy approaches in diagnosis and treatment help the client feel relieved for a short time, the individual who comes back to the environment that is the cause of the problems begins having similar problems again. Recurrence and chronicization of the psychological problems will cause the clients to feel more sick or embarrassed (Worell 2001).

This results from the fact that the traditional models evaluate recovery according to the absence of the symptoms or the ability to control them and give less importance to the personal experiences.

Classically, recovery criteria in traditional models include independent living, working, no recurrence for two years and not using antipsychotic drugs (Moller and McLoughlin, 2013; O'Connor and Delaney, 2007).

Beside all these, full recovery cannot be achieved or recurrence cannot be prevented in the treatment of mental illnesses due to the negative sides of the Classic Psychiatric Approaches such as:

Ignoring individual characteristics such as socio-cultural aspects, ethnicity, race, gender,

Presence of the superior-subordinate relationship within the counselor-client relationship,

The development of the theories by men who usually grew up in a patriarchal system, and therefore, emergence of the approaches which are man-oriented and consider masculinity as a sigh of power,

Therapists' consideration of their own value system in the center of the therapeutic relationship,

Lack of an individual-specific approach, not paying attention to the socio-cultural environment of the client,

Supporting the traditional gender roles and usually having prejudgments against women,

Usage of gender-based terms especially in the psychoanalytic approach.

Classic approaches can be inadequate when it comes to the values, feelings, goals, abilities and the change in the roles of the individuals who are experiencing mental illnesses, and to have a satisfactory, hopeful and meaningful life (Corey, 2015; Molley, 2013; Murdock, 2012; O'Connor and Delaney, 2007; Sayar, 2014)

\section{Gender-Sensitive Approaches as Alternatives to Classic Psychiatric Approaches: Feminist Therapy}

Feminist therapy first appeared in the USA in the 1970s and it originated from the female liberation movement. Feminist therapy which is based on the term of equality of the feminist theory emphasizes the social sensitivity (Negy and McKinney, 2014). Feminist therapy is a modern psychiatric approach particularly addressing the needs of women and aiming at radical changes in society (Uçar, Y1ldz, Bilgin and Bastemur, 2016).

Feminist therapy proposes new suggestions for the nature of women, the reasons behind women's psychological problems, the psychological help services rendered to women, the therapist-patient relationship, the role of the therapist, therapeutic interventions and the purposes of the therapy (Evans, 2005; Pehlivan 2015). It aims at establishing an equal relationship between the counselor and the client and increasing the client's power, authority and autonomy (Brown and Bryan, 2007). Feminist therapy concentrates on women's living their potential, diversity, socio-cultural-political gender equality and the value of women's experiences (Uçar, 2016). Therefore, a series of principles have been established for feminist therapy on the basis of feminist philosophy.

The personal is political. This principle relies on the assumption that individual problems which individuals present to counselors emerge in political and social contexts.

The practices within the therapy should aim at not only helping the clients with their struggles but also enabling the social change.

Experiences, voices and experiences of women are precious and women should be honored. Women should be considered as the center for their problems to be understood.

The consultation relationship is egalitarian. Feminist therapists object to an imbalance of power in the relationship with a client. Clients should be considered experts regarding their lives.

The focus should be set on the strengths of the client and the psychological issues should be re-defined. Some feminist therapists even refuse the diagnosis of mental illnesses and the illness models.

The sociocultural environments of the clients can be understood in a better way. For this reason, the sociocultural environment should also be taken into consideration while evaluating an individual (Corey, 2015; Murdock, 2012).

The view of human nature which feminist therapy is based on is the most basic point that differentiates it from other theories.

Other theories evaluate the individuals considering their biological sexes. Intrapsychic, male-dominant gender- or race-centered theories suggest different development paths for women and men, thinking that human development is similar for everyone and attributing the faced problems to the previous experiences. Feminist therapy explains human development with 3 basic approaches. 
It is flexible and multicultural; it deals with individuals without any gender, age, racial and cultural discrimination.

It is interactive, focuses on individuals' experiences and approaches the individuals in terms of their emotions, thoughts and behaviors.

It concentrates on the lifetime; it suggests that human development continues during the whole life (Murdock, 2012).

Feminist therapists have developed different techniques appropriate for the philosophy they rely on in order to support women and men both psychologically and sociologically. The gender role analysis and power analysis are used for defining the client's problems. Apart from these, assertiveness training and techniques such as reframing and bibliotherapy can also be used.

The purpose of these techniques is to raise awareness for helping individuals to differentiate between what is healthy and what is socially imposed for them. For instance, in the gender role analysis, clients research the effect of stereotyped female-male behaviors in their cultures on their illness. In the power analysis, it is about gaining control over the life and noticing the available strengths.

While the aim is to increase the assertive behaviors of the client in the assertiveness training, reframing works on the re-evaluation of the situations by the clients. In bibliotherapy, creation of individual and social awareness is aimed through materials such as books, films and educational tapes (Murdock 2012; Sharf, 2010).

\section{Conclusion}

As a result, the psychological problems of women who apply to psychiatry usually arise from gender-related attitudes in the family and society. Because the services provided by the applied centers are rendered with the biomedical model and the mainstream therapy approaches based on the patriarchal system, they are inadequate to solve the problems, and the problems may even intensify. It is believed that approaching patients with a feminist perspective in these institutions will give the individuals the opportunity of social and emotional development in their daily lives. Feminist therapy, which enables individuals to get rid of their feelings of guilt, discover their strengths and acquire new skills, will also help them take part in the public space more often and struggle with the practices that cause them to suffer in their circumstances in a better way.

\section{Declarations}

Ethics Approval and Consent to Participate Not applicable.

\section{Consent for Publication}

Not applicable.

\section{Availability of Data and Materials}

Not applicable.

\section{Competing Interests}

The author declares that no competing interests in this manuscript.

\section{Funding}

Not applicable.

Authors' Contributions

The author (VK) worked as the primary responsible in all areas of the study, read and approved the final version of the article.

\section{References}

Altınova, H. H., \& Duyan, V. (2013). The Validity and Reliability of Perception of Gender Scale. Society and Social Work, 24(2): 922

Aston, V. \& Coffey, M. (2012). Recovery: What Mental Health Nurses and Service Users Say About the Concept of Recovery. $J$ Psychiatr Ment Health Nurs 19:257-63.

Bal, D. M. (2014). General Overview of Gender Inequalities. Journal of Women's Health Nursing, 1(1):15-28.

Çakır, H. (2016). Kadınların Sınıfı: Ücretli Ev Emeği ve Kadın Öznelliğinin İnşası. International Journal of Euroasian Research, 4(8): 266-284

Çepikkurt. F. \& Coşkun, F. (2010). Social Physique Anxiety and Body Image Satisfaction Levels of Collegian Dancers. Pamukkale Spor Sciences Journal, 1: 17-24.

Corey, G. (2015). Theory and Practice of Counseling and Psychotherapy. Nelson Education.

Craske, M.G. \& Stein, M.B. (2016). Anxiety. The Lancet, 388: 3048-59

Davison, G. C., \& Neale, J. M. (1974). Abnormal Psychology: An Experimental Clinical Approach. Oxford, England, John Wiley \& Sons.

Dökmen, Z. Y. (2010). Toplumsal Cinsiyet-Sosyal Psikolojik Açıklamalar. İstanbul, Remzi Kitapevi.

Dündar, Ö. Z. (2012). The Reflection of Gender Roles in Television Advertisement. Ethos: Dialogues In Philosophy And Social Sciences, 5(1): 121-136.
Eaton, N. R., Keyes, K. M., Krueger, R. F., Balsis, S., Skodol, A. E., Markon, K. E., ... \& Hasin, D. S. (2012). An Invariant Dimensional Liability Model of Gender Differences in Mental Disorder Prevalence: Evidence from a National Sample. Journal of Abnormal Psychology, 121(1), 282.

Evans, K. M., Kincade, E. A., Marbley, A. F., \& Seem, S. R. (2005). Feminism and feminist therapy: Lessons from the past and hopes for the future. Journal of Counseling \& Development, 83(3), 269-277.

Sayar, K. (2003). Kültür ve Ruh Sağlığ1: Küreselleşme Koşullarında Kültürel Psikiyatri. İstanbul, Metis Yayınları.

Herman, J. L. (2016). Travma ve İyileşme: Şiddetin Sonuçları Ev İçi Istismardan Siyasi Teröre. (Edt: Tosun, T.). İstanbul: Literatür Yayıncılık.

Keskini, A., Ünlüoglu, İ., Bilge, U., \& Yenilmez, Ç. (2013). The Prevalence of Psychiatric Disorders Distribution of Subjects Gender and its Relationship with Psychiatric HelpSeeking. Archives of Neuropsychiatry, 50(4): 344-351.

Kessler, R. C. (2007). The Global Burden of Anxiety and Mood Disorders: Putting the European Study of the Epidemiology of Mental Disorders (ESEMeD) Findings into Perspective. J. Clin. Psychiatry, 68(2):10-19

Koyun, A., Taşkın, L., \& Terzioğlu, F. (2011). Yaşam dönemlerine göre kadın sağlığı ve ruhsal işlevler: Hemşirelik yaklaşımlarının değerlendirilmesi. Current Approaches in Psychiatry, 3(1), 67-99. 
Knapp, M. (2007). Mental Health Policy and Practice across Europe: The Future Direction of Mental Health Care. McGraw Hill International, Maidenhead.

Moller, M. D. \& McLoughlin, K. A. (2013). Integrating Recovery Practices into Psychiatric Nursing: Where Are We in 2013? J Am Psychiatr Nurses Assoc, 19:113-6.

Murdock, N. L. (2012). Theories Of Counseling and Psychotherapy: A Case Approach. Pearson Education New Zealand.

Negy, C. \& McKinney, C. (2006). Application of Feminist Therapy: Promoting Resiliency Among Lesbian and Gay Families. Journal of Feminist Family Therapy, 18:(1-2): 67-83

O'Connor, F.W. \& Delaney, K. R. (2007). The Recovery Movement: Defining Evidence-Based Processes. Arch Psychiatr Nurs, 21:172-5.

Öz, F. \& Yilmaz, E. B. (2009). A Significant Concept in Protecting Mental Health: Resilience. Hacettepe University Faculty of Health Sciences Nursing Journal, 16(3): 82-89

Özcan, H., Subaşı, B., Budak, B., Çelik, M., Gürel, Ş. C., \& Yıldız, M. (2013). Relationship Between Self-Esteem, Social Appearence Anxiety, Depression and Anxiety in Adolescent and Young Adult Women. Journal of Mood Disorders, 3(3): 107-13.

Pehlivan, H. (2015). A Critical Feminist Therapy Perpsective on Psychological Help for Women. Fe Journal. 7(2): 95-104.

Powell, G.N. \& Greenhaus, J.H. (2010). Sex, Gender, and Decisions at The Family - Work Interface. Journal of Management. 36(4): 1011-1039.

Sayar K. (2014). Terapi-Kültürel Bir Eleştiri. İstanbul, Timaş Yayınları

Sezgin, D. (2015) Toplumsal Cinsiyet Perspektifinde Sağlık ve Tıbbileştirme. Sosyoloji Araştırmaları Dergisi, 18(1): 153-186.

Sharf, R.S. (2010). Theories of Psychotherapy and Counseling Concepts and Cases. Brooks - Cole Cengage Learning, Belmont.

Stapleton, J. A., Taylor, S., \& Asmundson, G. J. (2007). Efficacy of various treatments for PTSD in battered women: Case studies. Journal of Cognitive Psychotherapy, 21(1), 91.
Topuz, S. K., \& Erkanli, H. (2016). Metaphor Analysis of Meanings Attributed to Women and Men in the Context Gender. Alternative Politica, 8(2): 300-321.

Türmen, T. (2003). Toplumsal Cinsiyet ve Kadın Sağlığı. Toplumsal Cinsiyet, Sağlık ve Kadın. In A. Akın (Ed.). Hacettepe Üniversitesi Kadın Sorunları Araştırma ve Uygulama Merkezi (HÜKSAM). Ankara, HÜ Publications.

Uçar, S., Yıldız, Y., Bilgin, M. D., \& Bastemur, Ş. (2016). Turkish Counselors' Perspectives toward Feminist Therapy. Procedia Social and Behavioral Sciences 217: 1176-1184

Üner, S. (2008). Toplumsal Cinsiyet Eşitliği, Kadına Yönelik Aile İçi Şiddetle Mücadele Projesi. T.C Başbakanlık Kadının Statüsü Genel Müdürlüğü, Ankara.

WHO, (2000). Women of South-East Asia: A Health Profile. New Delhi, World Health Organization, Regional Office for South East Asia Region.

Wittchen, H. U., Jacobi, F., Rehm, J., Gustavsson, A., Svensson, M., Jönsson, B., ... \& Fratiglioni, L. (2011). The Size and Burden of Mental Disorders and Other Disorders of the Brain in Europe 2010. European neuropsychopharmacology, 21(9): 655-679

Worell, J. (2001). Feminist Interventions: Accountability Beyond Symptom Reduction. Psychology of Women Quarterly, 25:335343.

World Health Organization. (2002). WHO Gender Policy: Integrating Gender Perspectives in the Work of WHO. Geneva, World Health Organization.

World Health Organization. (2009). The European Health Report 2009: Health and Health Systems, Copenhagen, World Health Organization, Regional Office for Europe.

World Health Organization. (2013). Mental Health Action Plan: 2013-2020. Geneva.

Yardım, N. (2001). Cinsiyet; Sağlık ve Yoksulluk. Aktuel Tip Dergisi, 6(1):78-82.

Yüksel, N. (2014). Ruhsal Hastalıklar. İstanbul, MN Medikal ve Nobel Tip Kitabevi. 